\title{
Ecoregional variations of aboveground biomass and stand structure in evergreen broadleaved forests
}

\author{
Tran Van Do ${ }^{1,2}$ - Mamoru Yamamoto ${ }^{1}$ Osamu Kozan ${ }^{3}$ - Vo Dai Hai ${ }^{4}$. \\ Phung Dinh Trung ${ }^{2}$. Nguyen Toan Thang ${ }^{2}$ Lai Thanh $\mathrm{Hai}^{2} \cdot$ Vu Thanh Nam ${ }^{5}$. \\ Trieu Thai Hung ${ }^{2} \cdot$ Hoang Van Thang ${ }^{4}$ Tran Duc Manh $^{2} \cdot$ Cao Chi Khiem ${ }^{2}$. \\ Vu Tien Lam $^{2}$ - Nguyen Quang Hung ${ }^{2}$ Tran Hoang Quy ${ }^{2}$ Pham Quang Tuyen ${ }^{2}$. \\ Trinh Ngoc Bon ${ }^{2} \cdot$ Nguyen Thi Thu Phuong $^{2} \cdot$ Ninh Viet Khuong ${ }^{2} \cdot$ \\ Nguyen Van Tuan ${ }^{2} \cdot$ Dang Thi Hai $\mathrm{Ha}^{2}$ - Tran Hai Long ${ }^{2} \cdot$ Dang Van Thuyet ${ }^{2}$. \\ Dang Thinh Trieu ${ }^{2}$ - Nguyen Van Thinh ${ }^{2}$ - Tran Anh Hai ${ }^{2}$ - Duong Quang Trung ${ }^{2}$. \\ Nguyen Van Bich ${ }^{2}$. Dinh Hai Dang ${ }^{2}$ Pham Tien Dung ${ }^{2}$ - Nguyen Huy Hoang ${ }^{2}$. \\ Le Thi Hanh ${ }^{2}$ - Phan Minh Quang ${ }^{2}$ Nguyen Thi Thuy Huong ${ }^{2}$ Hoang Thanh Son ${ }^{2}$. \\ Nguyen Thanh $\mathrm{Son}^{2} \cdot$ Nguyen Thi Van $\mathrm{Anh}^{2} \cdot$ Nguyen Thi Hoai Anh ${ }^{2} \cdot$ \\ Pham Dinh Sam ${ }^{2}$ Hoang Thi Nhung ${ }^{2}$ Hoang Van Thanh ${ }^{2} \cdot$ Nguyen Huu Thinh ${ }^{2}$. \\ Tran Hong $\operatorname{Van}^{2} \cdot$ Ho Trung Luong ${ }^{2} \cdot$ Bui Kieu Hung ${ }^{2}$
}

Received: 10 January 2018 / Accepted: 13 May 2018/Published online: 16 May 2019

(C) The Author(s) 2019

\begin{abstract}
Biotic and abiotic factors control aboveground biomass (AGB) and the structure of forest ecosystems. This study analyses the variation of AGB and stand structure of evergreen broadleaved forests among six ecoregions of Vietnam. A data set of 173 1-ha plots from 52 locations in undisturbed old-growth forests was developed. The results indicate that basal area and AGB are closely correlated

Project funding: This word is funded by Vietnam Ministry of Science and Technology under Grant number ĐTĐL.XH.10/15, Vietnam National Foundation for Science \& Technology Development (106NN.06-2016.10), and International Foundation for Science (J-1-D4602-3).
\end{abstract}

The online version is available at http://www.springerlink.com

Corresponding editor: Yu Lei.

Tran Van Do

dotranvan@hotmail.com

1 Research Institute for Sustainable Humanosphere, Kyoto University, Uji, Kyoto, Japan

2 Silviculture Research Institute, Vietnamese Academy of Forest Sciences, North Tu Liem, Hanoi, Vietnam

3 Center for Southeast Asian Studies, Kyoto University, Kyoto, Japan

4 Vietnamese Academy of Forest Sciences, North Tu Liem, Hanoi, Vietnam

5 Vietnam Administration of Forestry, No. 2 Ngoc Ha, Ba Dinh, Hanoi, Vietnam with annual precipitation, but not with annual temperature, evaporation or hours of sunshine. Basal area and AGB are positively correlated with trees $>30 \mathrm{~cm} \mathrm{DBH}$. Most areas surveyed $(52.6 \%)$ in these old-growth forests had AGB of 100-200 Mg ha ${ }^{-1} ; 5.2 \%$ had AGB of 400-500 Mg ha ${ }^{-1}$, and $0.6 \%$ had $\mathrm{AGB}$ of $>800 \mathrm{Mg} \mathrm{ha}^{-1}$. Seventy percent of the areas surveyed had stand densities of 300-600 ind. $\mathrm{ha}^{-1}$, and $64 \%$ had basal areas of $20-40 \mathrm{~m}^{2} \mathrm{ha}^{-1}$. Precipitation is an important factor influencing the AGB of old-growth, evergreen broadleaved forests in Vietnam. Disturbances causing the loss of large-diameter trees (e.g., $>100 \mathrm{~cm}$ DBH) affects AGB but may not seriously affect stand density.

Keywords Aboveground biomass - Carbon storage . Climatic variables · Ecoregion · Edaphic variables · Oldgrowth forest

\section{Introduction}

The importance of forest structure to ecosystem function and biodiversity is well-recognized (Reilly and Spies 2015), however, variation in structure at a regional scale is poorly understood. Ecoregions are large areas that contain a number of ecosystems. They are geographical zones that represent groups or associations of similarly functioning ecosystems (Bailey 1983). The differences in biotic and 
abiotic factors lead to differences in ecosystem structures and functions.

Forests account for $80 \%$ of the earth's plant biomass (Kindermann et al. 2008), and contain more carbon in biomass and soils than in the atmosphere $\mathrm{CO}_{2}$ (Pan et al. 2011). The aboveground biomass (AGB) integrates the processes of plant growth, recruitment and mortality, as well as succession and disturbance. It is influenced by climate, edaphic conditions, species composition, and topography (Muller-Landau et al. 2006; Urquiza-Haas et al. 2007). The AGB of tropical forests is a key property of ecosystems which plays an important role in the global carbon cycle, accounting for a significant fraction of the total carbon pool and nutrient stocks (Brown et al. 1995; Phillips et al. 1998; Chapin et al. 2002; Fahey and Knapp 2007). Because the AGB varies across landscapes and forest types (Saatchi et al. 2007; Houghton et al. 2009), estimating local and regional aboveground biomass provides data for understanding the forest carbon cycle (Urquiza-Haas et al. 2007; Houghton et al. 2009; Loarie et al. 2009).

Low-latitude forests are estimated to contain approximately $60 \%$ of the AGB in the world forests (Dixon et al. 1994). Nevertheless, there is still uncertainty about the AGB of tropical forests (Brown 1997; Zheng et al. 2016). A better understanding of tropical aboveground biomass distribution is of theoretical and practical interest (Schimel 1995). Because AGB is determined by the size and frequency distribution of species, opportunities for improving estimates of carbon stocks is to further our understanding of factors causing variations in forest structure. Structure and AGB of tropical forests reflect edaphic conditions (Pires and Prance 1985; Tuomisto et al. 1995; Laurance et al. 1999; Lee et al. 2018), climate (Holdridge 1979; Gentry 1982; Pandian and Parthasarathy 2016), disturbance regimes (Lugo and Scatena 1996), successional status (Saldarriaga et al. 1988), and human impacts (Laurance et al. 1997). However, the degree to which the structure of old-growth tropical forests vary across large scale landscapes (ecoregions) is not fully understood.

The aboveground biomass is an important part of carbon storage in forests (Sierra et al. 2007; Malhi et al. 2009). In tropical forests worldwide, about $50 \%$ carbon is stored in AGB (Dixon et al. 1994). However, there are significant differences among sites. For example, a moist tropical forest in Africa has more than three times as much carbon in the aboveground biomass than in the soil (Djomo et al. 2011); a tropical forest in Peru has twice the amount of carbon stored in the soil as in the AGB (Gibbon et al. 2010). A selectively-logged, lowland dipterocarp forest in Malaysia contains twice as much carbon in AGB as in the soil (Saner et al. 2012), and a secondary forest in the
Philippines contains 50\% more carbon in aboveground biomass than in the soil (Lasco et al. 2004).

Vietnam has a monsoon climate and stretches from $8^{\circ} 34^{\prime}$ to $23^{\circ} 23^{\prime} \mathrm{N}$ and from $102^{\circ} 09^{\prime}$ to $109^{\circ} 24^{\prime} \mathrm{E}$ with over $3000 \mathrm{~km}$ of coastline. North and South Vietnam are divided by the Hai Van Pass at $16^{\circ} 11^{\prime} \mathrm{N}$. In the North, there are four seasons: spring, summer (a rainy season), autumn and winter (a dry season); and there are two seasons (rainy and dry) in the South. Differences of climate and topography created eight ecoregions in Vietnam (Fig. 1), the Northwest (NW), Northeast (NE), Red River Delta (RRD), North Central Coast (NCC), South Central Coast (SCC), Central Highland (CH), Southeast (SE), and the Mekong River Delta (MRD). The objective of this study was to analyze variations in stand density and aboveground biomass in the ecoregions of Vietnam.

\section{Materials and methods}

\section{Old-growth forest inventory data}

Tree inventory data on old-growth forests were selected showing that survey plots were undisturbed. The criteria to identify old-growth forests included: (1) there were no cut stumps found on the site; (2) it is difficult to access to the site; and, (3) there was a thick layer of organic matter. A data set of 173 1-ha plots was assembled which were surveyed in 52 locations distributed in six of eight

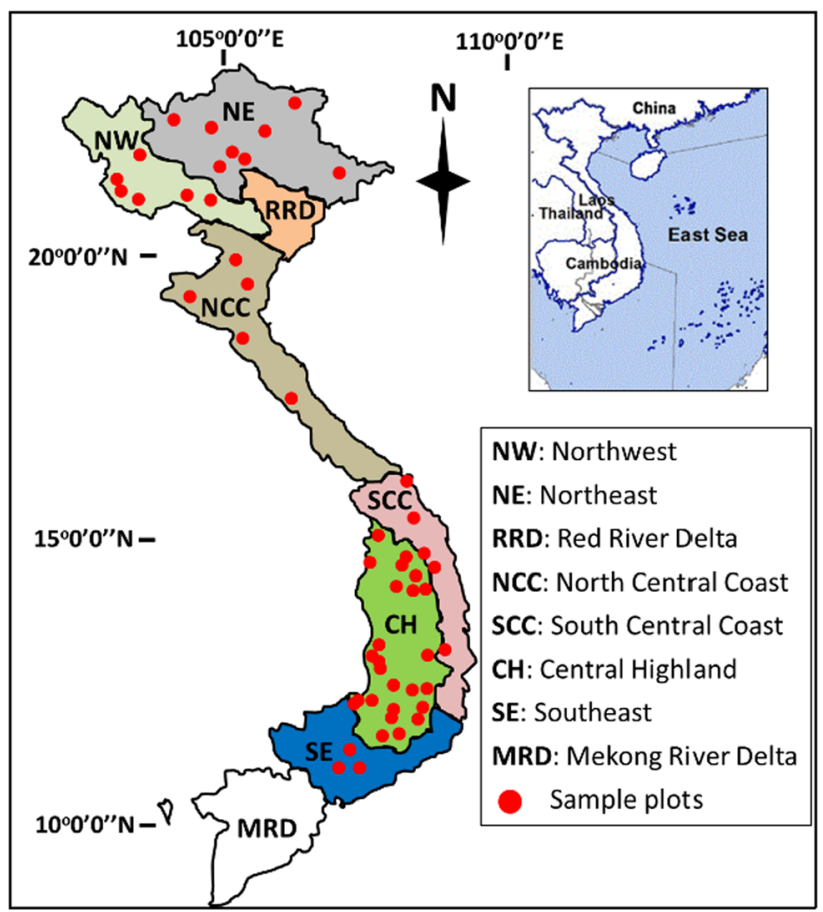

Fig. 1 Ecoregions of Vietnam and the location of sample plots 
Table 1 Climate (annual mean \pm SE) and main soil types in the ecoregions of Vietnam

\begin{tabular}{llllll}
\hline Ecoregion & $\begin{array}{l}\text { Annual } \\
\text { temperature }\left({ }^{\circ} \mathrm{C}\right)\end{array}$ & $\begin{array}{l}\text { Annual precipitation } \\
(\mathrm{mm})\end{array}$ & $\begin{array}{l}\text { Annual evaporation } \\
(\mathrm{mm})\end{array}$ & $\begin{array}{l}\text { Annual hours of } \\
\text { sunshine }\end{array}$ & Main soil types \\
\hline $\begin{array}{l}\text { Northwest (NW) } \\
\text { Northeast (NE) }\end{array}$ & $18.1 \pm 0.4^{\mathrm{a}}$ & $1768 \pm 37.9^{\mathrm{a}}$ & $835 \pm 14.8^{\mathrm{a}}$ & $1674 \pm 24.8^{\mathrm{a}}$ & Acrisols, Alisols, Ferralsols \\
$\begin{array}{l}\text { North Central Coast } \\
(\mathrm{NCC})\end{array}$ & $20.1 \pm 0.4^{\mathrm{b}}$ & $1836 \pm 41.1^{\mathrm{a}}$ & $828 \pm 10.4^{\mathrm{a}}$ & $1400 \pm 14.7^{\mathrm{b}}$ & $\begin{array}{c}\text { Acrisols, Calcisols, Ferralsols } \\
\text { Acrisols, Ferralsols, Gleysols, } \\
\text { Leptosols }\end{array}$ \\
$\begin{array}{l}\text { South Central Coast } \\
(\mathrm{SCC})\end{array}$ & $21.8 \pm 0.6^{\mathrm{b}}$ & $2052 \pm 93.4^{\mathrm{b}}$ & $1170 \pm 33.5^{\mathrm{c}}$ & $2249 \pm 34.9^{\mathrm{d}}$ & $\begin{array}{c}\text { Acrisols, Ferralsols, Gleysols, } \\
\text { Leptosols }\end{array}$ \\
$\begin{array}{l}\text { Central Highland } \\
(\mathrm{CH})\end{array}$ & $18.9 \pm 0.5^{\mathrm{a}}$ & $1924 \pm 79.4^{\mathrm{ab}}$ & $972 \pm 34.3^{\mathrm{b}}$ & $2061 \pm 53.7^{\mathrm{e}}$ & $\begin{array}{c}\text { Acrisols, Ferralsols, Leptosols, } \\
\text { Solochats }\end{array}$ \\
$\begin{array}{l}\text { Southeast (SE) } \\
\text { S }\end{array}$ & $21.9 \pm 1.1^{\mathrm{b}}$ & $1804 \pm 72.1^{\mathrm{a}}$ & $1233 \pm 25.0^{\mathrm{c}}$ & $2375 \pm 51.3^{\mathrm{f}}$ & $\begin{array}{c}\text { Acrisols, Ferralsols, Fluvisol, } \\
\text { Solochats }\end{array}$ \\
\hline
\end{tabular}

ANOVA (single factor) analysis: annual temperature, $\mathrm{F}_{(5,75)}=2.8$ and $p<0.05$ indicate significant difference among ecological regions; annual precipitation, $\mathrm{F}_{(5,75)}=2.9$ and $p<0.01$ indicate significant difference among ecological regions; annual evaporation, $\mathrm{F}_{(5,75)}=3.8$ and $p<0.005$ indicate significant difference among ecological regions; annual hours of sunshine $\mathrm{F}_{(5,75)}=11.1$ and $p<0.001$ indicate significant difference among ecological regions. Different letters ${ }^{a, b}, \mathrm{c}$ in each column indicate significant difference of means by Tukey post hoc test at $p=0.05$

ecoregions, excluding RRD and MRD which did not have old-growth forests (Fig. 1). Annual temperatures and precipitation, and main soil types of each ecoregion are indicated in Table 1. All locations were located in national parks, natural preserve areas, biodiversity protection areas, or community forests which are protected for spirits. In each surveyed plot, data collected included the list of all trees, and DBH (only trees with diameter at breast height $\geq 10 \mathrm{~cm}$ ).

\section{Aboveground biomass determination}

Dry AGB was based on DBH as follows (Bao et al. 2016):

$$
\mathrm{AGB}=0.12843 \mathrm{DBH}^{2.409074}
$$

The sum of AGB of all trees is the AGB of the plot.

\section{Climate data}

Annual temperatures $\left({ }^{\circ} \mathrm{C}\right)$, precipitation $(\mathrm{mm})$, evaporation $(\mathrm{mm})$, and hours of sunshine were recorded from $109 \mathrm{cli}-$ mate monitoring stations distributed around sample locations for 2001-2014 (Table 1) (MARD 2014). The recorded data were used to estimate daily values, monthly values, and annual values step by step. The average annual values for the 14-year period were calculated for each ecological region (Table 1).

\section{Data analysis}

ANOVA (single factor) analysis examined the differences of means of stem density, basal area, and AGB among ecoregions; Tukey's post hoc test compared ecoregions.
Best-fitted regression was used to show the relationship between temperature, precipitation, evaporation and hours of sunshine, and growth parameters (stem density, basal area and AGB). All data analyses used SAS 9.2 (SAS Institute Inc., Cary, NC, USA).

\section{Results}

The lowest density was 210 ind. $^{-1}$ in the Central Highlands $(\mathrm{CH})$ and the highest 1095 stems ha ${ }^{-1}$ in the Northwest (NW). Basal area was lowest $\left(11.6 \mathrm{~m}^{2} \mathrm{ha}^{-1}\right)$ in the Northeast (NE) and highest $\left(87.2 \mathrm{~m}^{2} \mathrm{ha}^{-1}\right)$ in the South Central Coast (SCC). The highest AGB (910 $\mathrm{Mg} \mathrm{ha}^{-1}$ ) was found in the SCC and the lowest AGB (101 Mg ha $\left.{ }^{-1}\right)$ in the $\mathrm{CH}$. Ecoregions had significant effects on stem density, basal area, and AGB (Table 2). The mean stem densities in NW, SCC, and Southeast (SE) were significantly higher than that in NE and the North Central Coast (NCC). There were no significant differences in stem density in $\mathrm{CH}$ compared to other ecoregions (Table 2). There were three significant groups in terms of basal area, the highest was in SCC, a medium was in NW, NCC, SE and $\mathrm{CH}$, and the lowest occurred in NE. There were three significant groups for AGB similar to that for basal area (Table 2). The country-wide average for density is 495 ind. $\mathrm{ha}^{-1}, 30.2 \mathrm{~m}^{2}$ for basal area ha ${ }^{-1}$, and $230.1 \mathrm{Mg} \mathrm{ha}^{-1}$ AGB.

In all six ecoregions, more than $85 \%$ of trees, $45 \%$ of the basal area, and $33 \%$ of the AGB were distributed in the 10-40 cm DBH class (Figs. 2, 3, 4). Trees $>100 \mathrm{~cm} \mathrm{DBH}$ were less than $1 \%$ of the density, $14 \%$ of the basal area, and $17 \%$ of the AGB. The general pattern was fewer trees 
Table 2 Stand density, basal area and aboveground biomass (AGB) of evergreen broadleaved forests in ecoregions of Vietnam (mean \pm SE)

\begin{tabular}{lccllc}
\hline Ecoregion & No. plot & Survey locations & Stem density (ind. ha $\left.{ }^{-1}\right)$ & ${\text { Basal area }\left(\mathrm{m}^{2} \text { ha }^{-1}\right)}_{\text {AGB }\left(\mathrm{Mg} \mathrm{ha}^{-1}\right)}$ \\
\hline Northwest (NW) & 10 & 6 & $629 \pm 91^{\mathrm{b}}$ & $34.9 \pm 3.8^{\mathrm{a}}$ & $260.9 \pm 35.7^{\mathrm{a}}$ \\
Northeast (NE) & 17 & 8 & $471 \pm 26^{\mathrm{a}}$ & $25.7 \pm 2.0^{\mathrm{b}}$ & $199.0 \pm 22.0^{\mathrm{b}}$ \\
North Central Coast (NCC) & 13 & 5 & $329 \pm 35^{\mathrm{a}}$ & $31.1 \pm 3.0^{\mathrm{a}}$ & $241.0 \pm 26.4^{\mathrm{a}}$ \\
South Central Coast (SCC) & 21 & 5 & $542 \pm 32^{\mathrm{b}}$ & $39.0 \pm 4.7^{\mathrm{c}}$ & $320.2 \pm 51.0^{\mathrm{c}}$ \\
Central Highland (CH) & 107 & 25 & $495 \pm 11^{\mathrm{ab}}$ & $28.9 \pm 0.9^{\mathrm{a}}$ & $214.9 \pm 8.2^{\mathrm{a}}$ \\
Southeast (SE) & 5 & 3 & $533 \pm 71^{\mathrm{b}}$ & $29.4 \pm 6.8^{\mathrm{a}}$ & $224.4 \pm 63.7^{\mathrm{a}}$ \\
Mean & & & $495 \pm 11$ & $30.2 \pm 0.9$ & $230.1 \pm 8.6$ \\
\hline
\end{tabular}

ANOVA (single factor) analysis: stem density, $\mathrm{F}_{(6,166)}=10.39$ and $p<0.05$ indicate no difference among ecological regions; basal area, $\mathrm{F}_{(6,166)}=16.88$ and $p<0.01$ indicate significant difference among ecological regions; $\mathrm{AGB}, \mathrm{F}_{(6,166)}=14.91$ and $p<0.05$ indicate significant difference among ecological regions. Different letters in each column indicate significant differences of means by Tukey's post hoc test at $p=0.05$
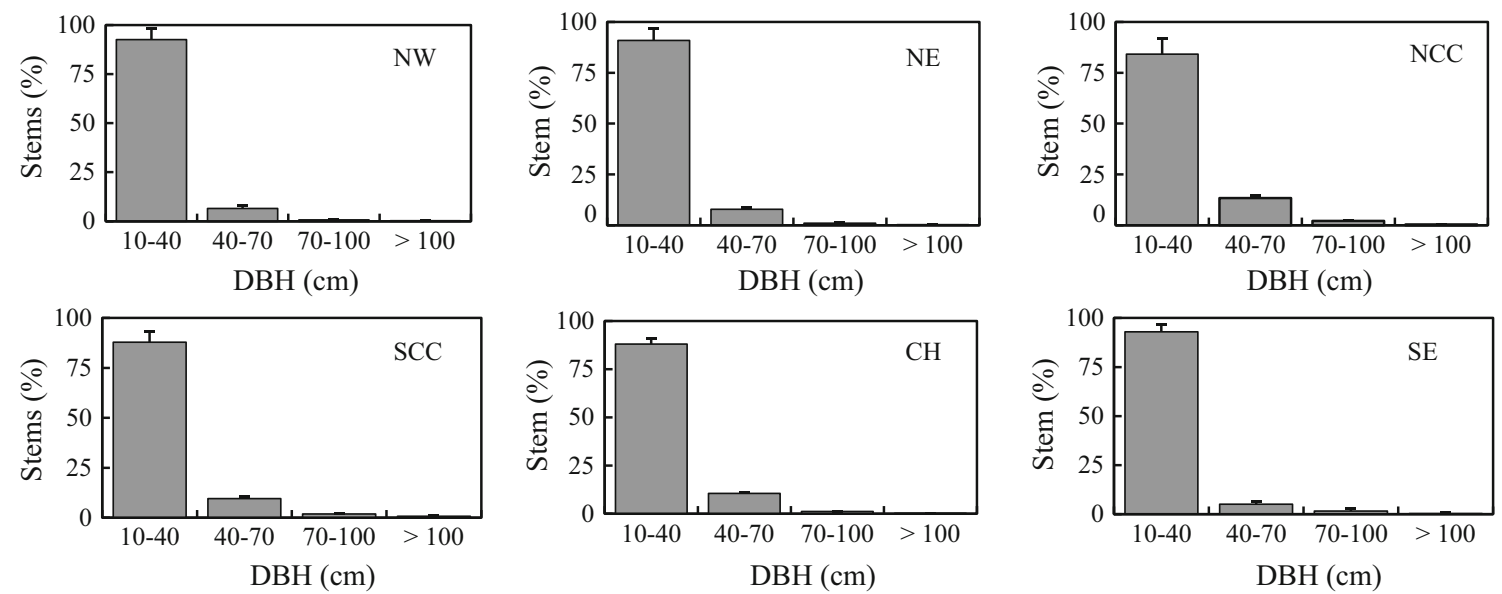

Fig. 2 Tree distribution by DBH class in ecoregions $(\mathrm{NW}=$ Northwest, NE = Northeast, $\mathrm{NCC}=$ North Central Coast, SCC = South Central Coast, $\mathrm{CH}=$ Central Highland, and $\mathrm{SE}=$ Southeast $)$. Bars indicate $\pm \mathrm{SE}$
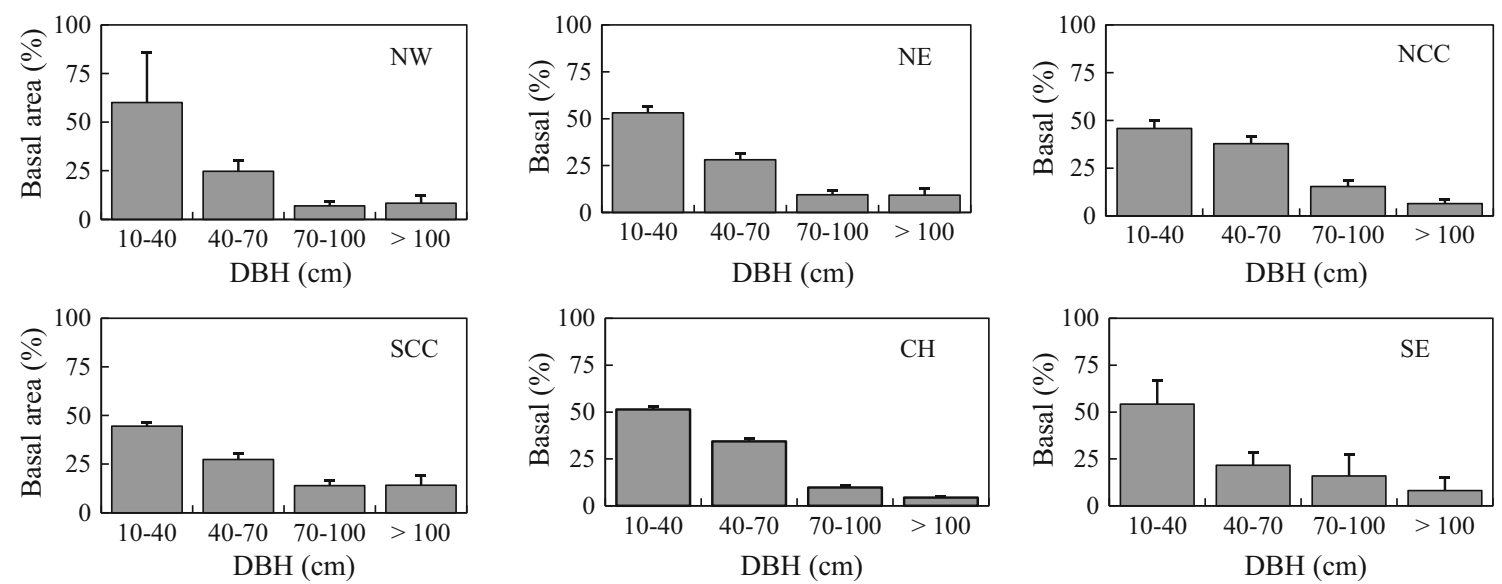

Fig. 3 Basal area distribution by DBH class in ecoregions $(\mathrm{NW}=$ Northwest, NE $=$ Northeast, NCC $=$ North Central Coast, SCC $=$ South Central Coast, $\mathrm{CH}=$ Central Highland, and $\mathrm{SE}=$ Southeast $)$. Bars indicate $\pm \mathrm{SE}$

(Fig. 2) and lower basal area (Fig. 3) in larger DBH classes. The AGB in trees $>100 \mathrm{~cm} \mathrm{DBH}$ in the NW, NE, and SCC ecoregions was higher than in the $70-100 \mathrm{~cm}$ DBH class (Fig. 4); AGB in the 40-70 cm DBH class in NCC was much higher than that in other DBH classes. 

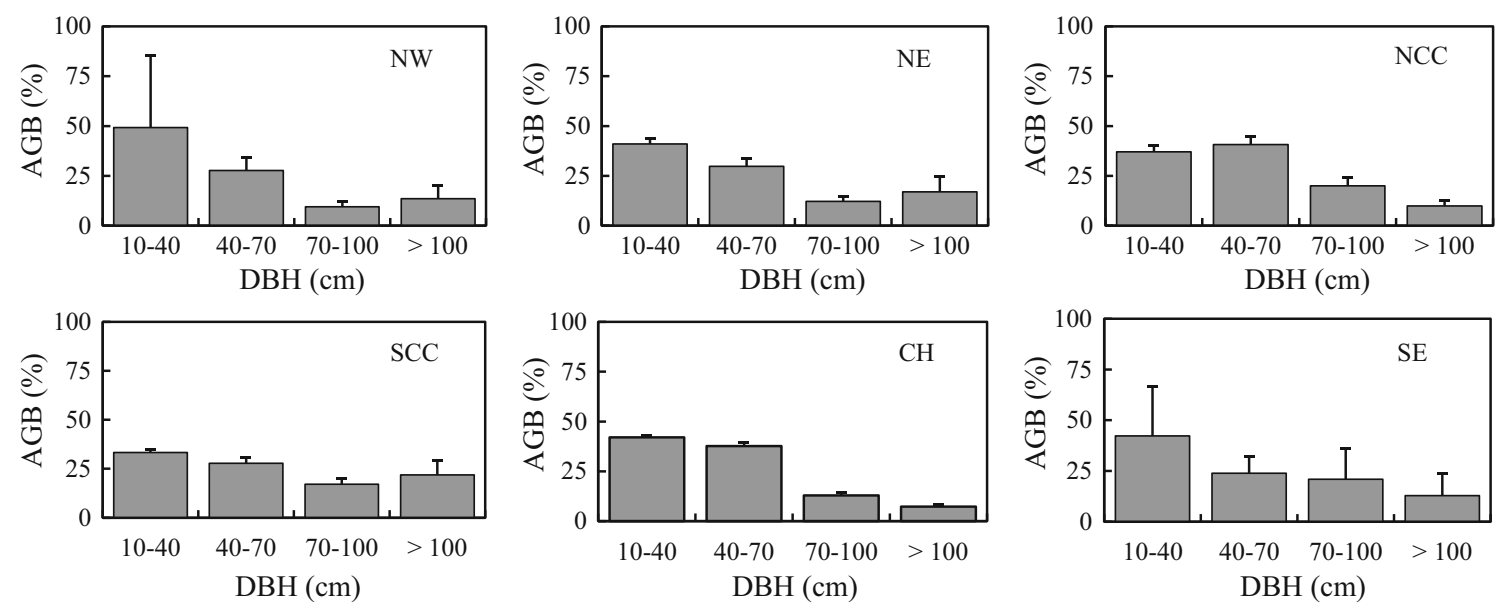

Fig. 4 Aboveground biomass (AGB) distribution by DBH class in ecoregions (NW $=$ Northwest, NE $=$ Northeast, NCC $=$ North Central Coast, $\mathrm{SCC}=$ South Central Coast, $\mathrm{CH}=$ Central Highland, and SE $=$ Southeast $)$. Bars indicate $\pm \mathrm{SE}$
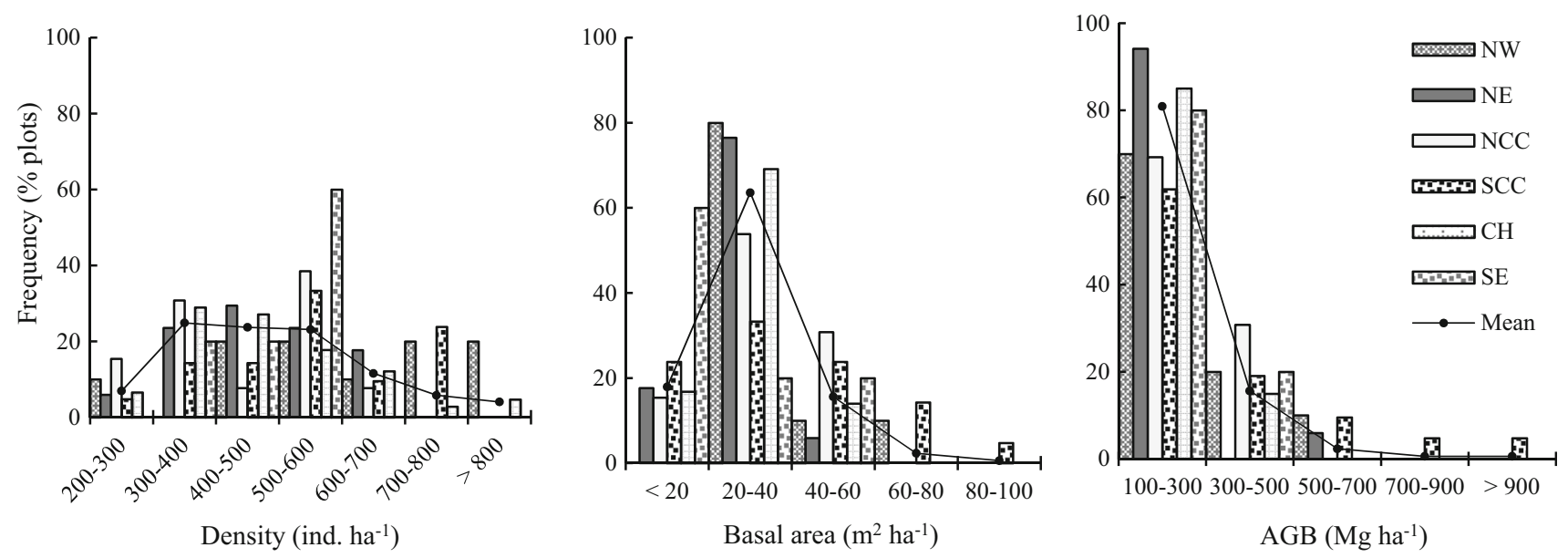

Fig. 5 Frequency distribution in tree, basal area, and aboveground biomass (AGB) classes in ecoregions $(\mathrm{NW}=\mathrm{Northwest}$, NE $=$ Northeast, $\mathrm{NCC}=$ North Central Coast, $\mathrm{SCC}=$ South Central Coast, $\mathrm{CH}=$ Central Highland, and SE $=$ Southeast $)$ and in all ecoregions combined $($ Mean $)$

Conversely, the reduction of AGB in larger DBH classes was found in $\mathrm{CH}$ and $\mathrm{SE}$ ecoregions (Fig. 4).

Only the NW and $\mathrm{CH}$ had stand densities $>800$ stems $\mathrm{ha}^{-1}$, while only the SCC had basal area $>80 \mathrm{~m}^{2} \mathrm{ha}^{-1}$. An AGB $>700 \mathrm{Mg} \mathrm{ha}^{-1}$ was found only in SCC (Fig. 5). Most plots (72\%) were in the range of 300-600 stems ha ${ }^{-1}$; $7 \%$ of the plots had 200-300 stems ha ${ }^{-1}$ while $4 \%$ of the plots had $>800$ ind. ha ${ }^{-1}$ (Fig. 5). Plots with basal areas of $20-40 \mathrm{~m}^{2} \mathrm{ha}^{-1}$ were $64 \%$ of the total number of plots, $18 \%$ of the plots with $<20 \mathrm{~m}^{2} \mathrm{ha}^{-1}$ and $16 \%$ of the plots in the range of $40-60 \mathrm{~m}^{2} \mathrm{ha}^{-1}$ (Fig. 5). Eighty-one percent of the plots had 100-300 $\mathrm{Mg} \mathrm{ha}^{-1}$ AGB (Fig. 5), 16\% had $300-500 \mathrm{Mg} \mathrm{ha}^{-1}$, and only $3 \%$ had $>500 \mathrm{Mg} \mathrm{ha}^{-1}$ AGB.

There was an exponential shape of the relationship between trees with $\mathrm{DBH}>30 \mathrm{~cm}$ and basal area, and between trees with $\mathrm{DBH}>30 \mathrm{~cm}$ and AGB. Basal area and AGB had a positive linear relationship (Fig. 6).
A linear relationship was best fitted for regression between climate variables (temperature, precipitation, evaporation, and hours of sunshine) and stand parameters (density, basal area, and AGB). However, regressions only existed between annual precipitation and basal area, and between annual precipitation and AGB (Fig. 7).

\section{Discussion}

Basal area and aboveground biomass are positively correlated with annual precipitation in this study (Fig. 7), which is consistent with other studies for tropical forests, for example, in Borneo (Slik et al. 2010), areas of Asia (Brown et al. 1993), the Amazon (Malhi et al. 2006; Saatchi et al. 2007), and African continent (Lewis et al. 2013). The AGB of tropical rain forests is controlled by environmental factors (Asner et al. 2009), as increased precipitation 

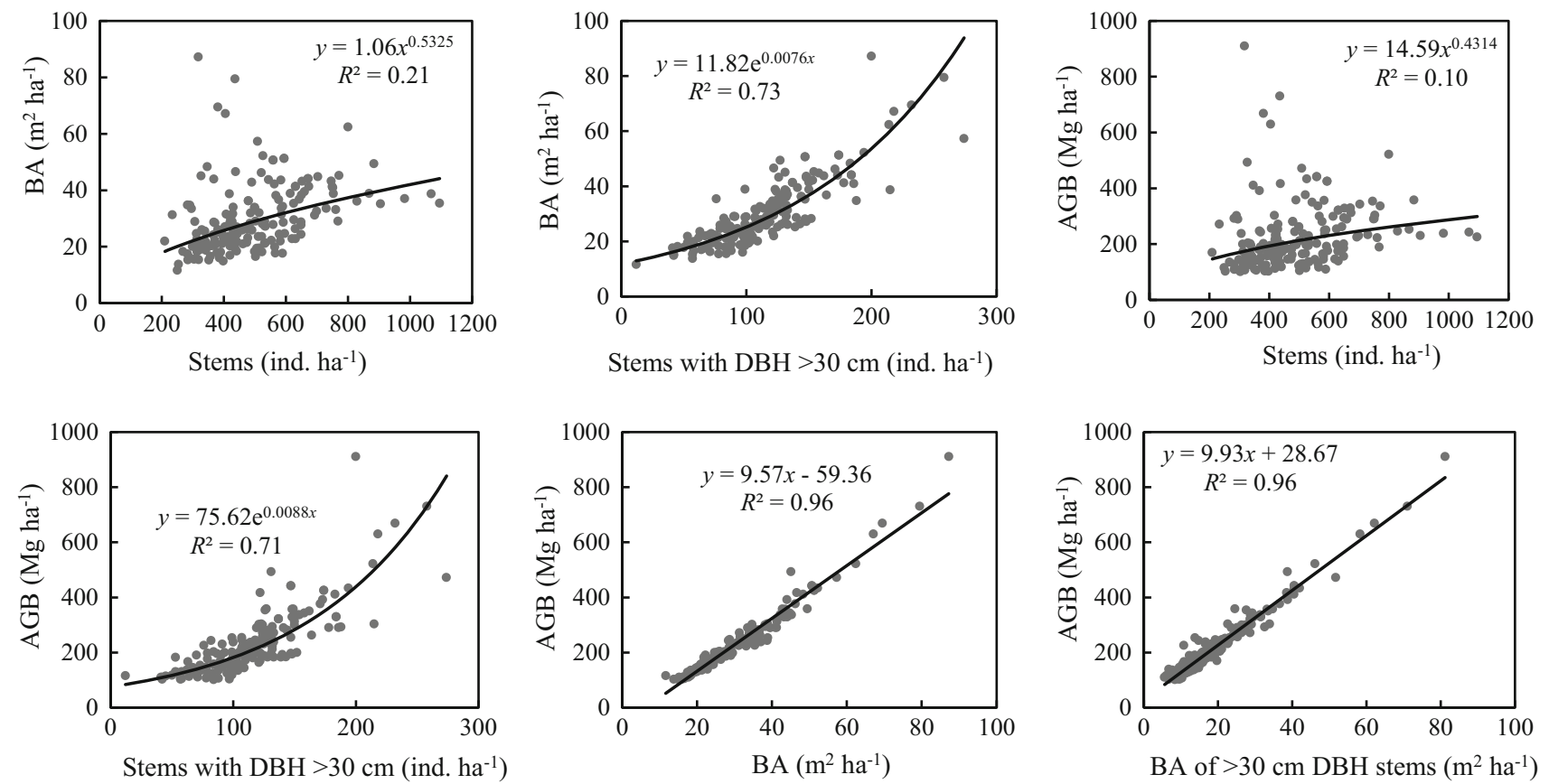

Fig. 6 Aboveground biomass (AGB) plotted against stems and basal area (BA), and BA plotted against stems for 173 plots in tropical evergreen broadleaved forests
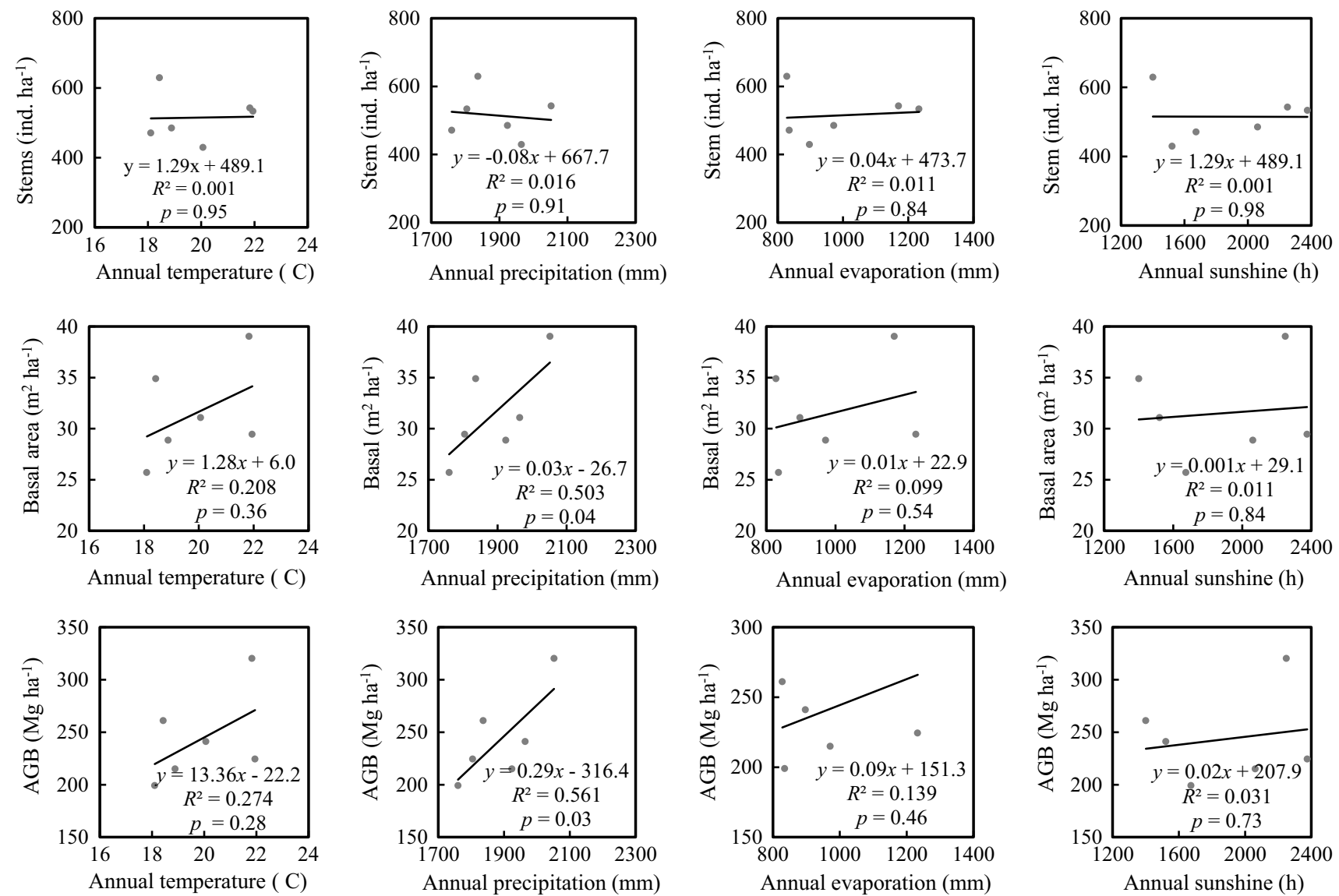

Fig. 7 Regression analysis between climate and stand parameters. Dots represent data of ecoregions 
enhances net primary production (Quesada et al. 2012; Lewis et al. 2013). Average AGB in each ecoregion and over all Vietnam (Table 2) was much lower than in Borneo's tropical forest (457.1 $\mathrm{Mg} \mathrm{ha}^{-1}$, Slik et al. 2010), the Amazonian tropical forest $\left(288.6 \mathrm{Mg} \mathrm{ha}^{-1}\right.$, Malhi et al. 2006), but was similar to AGB in Asian tropical forests (255 $\mathrm{Mg} \mathrm{ha}^{-1}$, Brown et al. 1993; Gibbs et al. 2007). Stand density for large trees (DBH $>70 \mathrm{~cm}$ ) accounted for $1.7 \%$ in this study, much lower than in Borneo (Slik et al. 2010). This is why the AGB of Vietnam's forests was much lower than in other studies as most AGB is stored in large-diameter trees (Slik et al. 2013). The importance of smalldiameter trees in storing AGB in Vietnam is well-recognized, as there was linear regression between $\mathrm{DBH}>30$ $\mathrm{cm}$ stems and AGB. Trees with DBH $>30 \mathrm{~cm}$ accounted for $76 \%$ of the AGB (Fig. 6). In addition, the high AGB in Borneo's forest was due to dominance of large-diameter dipterocarp trees (Paoli et al. 2008; Slik et al. 2010). There are no large-diameter, dominant tree species in any ecoregions of Vietnam (Vo et al. 2010, Tran et al. 2016, 2017a, b). However, such findings should be treated cautiously because AGB is never measured directly (Tashi et al. 2017; Westfall and McRoberts 2017), but is rather estimated by using imperfect allometries.

It is recognized that AGB in the Central Highland is highest among Vietnam's ecoregions (Le 1996; Vo et al. 2015). However, this study found that its AGB (241.9 $\mathrm{Mg} \mathrm{ha}^{-1}$ ) was among the middle class, where the highest AGB was in the South Central Coast (Table 2). This may be explained by high precipitation and temperatures (Table 1) and the long latitudinal distribution of this ecoregion may explain this, and results in a diversity of forest types and tree species in diverse climate, edaphic, and topographical conditions (Fig. 1). This ecoregion has a long coast line in the east and inland in the west and no winter, supporting a diverse growth of tree species. The lowest AGB in the Northeast ecoregion (Table 2) may be explained by low temperatures, precipitation, evaporation, and the lowest annual sunshine hours among the ecoregions (Table 1), and the difference in species composition (Tran et al. 2010; Vo et al. 2015). With only $1400 \mathrm{~h}$ of sunshine annually (Table 1), photosynthesis may be limited and with a winter season from November to March the growing season is limited to the summer months in the NE. However, the AGB in NE ecoregion was $260.0 \mathrm{Mg} \mathrm{ha}^{-1}$, the second highest among the six ecoregions. Such differences in AGB between the NE and NW ecoregions may be explained by difference in species composition and edaphic factors (Tran et al. 2010, 2011). However, further studies are needed, especially on the effects of edaphic conditions on AGB and stem density.

Thirty-two percent of tropical forests in Asia (Chave et al. 2008; Slik et al. 2010) and 40\% of African tropical

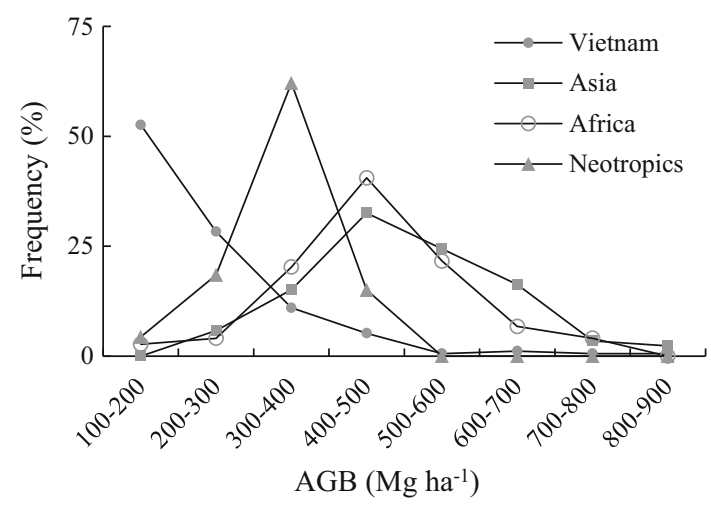

Fig. 8 Aboveground biomass (AGB) of global tropical forests. Data from Chave et al. (2008) and Slik et al. (2010) for Asia, Lewis et al. (2009) for Africa, Chave et al. (2008) and Malhi et al. (2006) for the Neotropics, and this study for Vietnam

forests (Lewis et al. 2009) had AGB of 400-500 $\mathrm{Mg} \mathrm{ha}^{-1}$ and $62 \%$ of Neotropical forests had AGB of 300-400 $\mathrm{Mg} \mathrm{ha}^{-1}$. However, 52.6\% old-growth, evergreen broadleaved forests in Vietnam only had AGB of 100-200 $\mathrm{Mg} \mathrm{ha}^{-1}$ (Fig. 8). Tropical forests may have AGB as high as $800-900 \mathrm{Mg} \mathrm{ha}^{-1}$. Studies report on the high variation of AGB among tropical forests and that biotic and abiotic factors influence different AGB (MullerLandau et al. 2006; Urquiza-Haas et al. 2007). Even on a small-scale as in Vietnam, the AGB among ecoregions is variable (Table 2). Therefore, regional as well as local studies on AGB and forest structure are needed to fully understand the role of forests on carbon storage against global warming and climate changes.

Low stand density in evergreen broadleaved forests in the NE, NCC, and CH ecoregions of Vietnam (Table 2) was similar to that in some tropical African forests (426 ind. ha ${ }^{-1}$, Lewis et al. 2013). However, higher stem density was also found in the NW, SCC, and SE ecoregions which was similar to that in Borneo (602 ind. ha ${ }^{-1}$, Slik et al. 2010) and in the Amazon (592 ind. ha ${ }^{-1}$, Lewis et al. 2004). These reflect the high variation of stem density among ecoregions of Vietnam which may be due to latitude (Fig. 1), resulting in seasonality between north and south, and from species differences. For example, there are no dominant species in any ecoregion (Tran et al. 2010; Vo et al. 2015) compared to Borneo forests dominated by dipterocarps (Slik et al. 2010) and central Africa forests dominated by Gilbertiodendron dewevrei (De Wild.) J.Leonard and Cynometra alexandri C.H.Wright (Lewis et al. 2013). Lewis et al. (2013) found the higher AGB of African forests near the equator, which is similar in this study where the highest AGB $\left(320 \mathrm{Mg} \mathrm{ha}^{-1}\right)$ was found in SCC near the equator (Fig. 1), followed by NW $\left(260 \mathrm{Mg} \mathrm{ha}^{-1}\right)$, and the lowest of $199 \mathrm{Mg} \mathrm{ha}^{-1}$ in $\mathrm{NE}$ furthest from the equator. 
In the old-growth, evergreen broadleaved forests of Vietnam, trees in $10-100 \mathrm{~cm}$ DBH classes accounted for $>99 \%$ of the stand density (Fig. 2), $>85 \%$ of the basal area (Fig. 3), and $>78 \%$ of AGB (Fig. 4). Any natural or anthropogenic disturbances (Miles and Kapos 2008; Slik et al. 2010, 2013; Miller et al. 2011; Pearson et al. 2014; Vo et al. 2015) such as typhoons or illegal logging removing large-diameter trees (e.g., $>100 \mathrm{~cm}$ $\mathrm{DBH})$ will significantly reduce carbon storage. Carbon loss in an ecosystem is increased by (1) removing carbon from the forest through timber removal, (2) disturbing soil that promotes organic matter decomposition, and (3) reducing forest cover leading to higher surface temperature which may promote higher soil microorganism activity, causing an increase in the rate of heterotrophic respiration.

In conclusion, the aboveground biomass of evergreen, broadleaved forests in Vietnam increased with higher annual precipitation but not with annual temperatures. There was no correlation between stand density, precipitation or annual temperatures. Correlations between aboveground biomass and edaphic conditions, and between stand density and edaphic conditions were not examined in this study because of data limitations. Such correlations should be conducted in the future to fully understand the effects of abiotic factors on aboveground biomass and stand structure of Vietnamese forests.

Open Access This article is distributed under the terms of the Creative Commons Attribution 4.0 International License (http://crea tivecommons.org/licenses/by/4.0/), which permits unrestricted use, distribution, and reproduction in any medium, provided you give appropriate credit to the original author(s) and the source, provide a link to the Creative Commons license, and indicate if changes were made.

\section{References}

Asner GP, Hughes RF, Varga TA, Knapp DE, Kennedy-Bowdoin T (2009) Environmental and biotic controls over aboveground biomass throughout a tropical rain forest. Ecosystems 12:261-278

Bailey RG (1983) Delineation of ecosystem region. Environ Manag $7: 365-373$

Bao H, Kralicek K, Poudel KP, Vu TP, Phung VK, Nguyen DH, Temesgen $H$ (2016) Allometric equations for estimating tree aboveground biomass in evergreen broadleaf forests of Viet Nam. For Ecol Manag 382:193-205

Brown S (1997) Estimating biomass and biomass change of tropical forests: a primer. Forestry Paper 134 . FAO, Rome

Brown S, Iverson LR, Prasad A, Liu D (1993) Geographical distributions of carbon in biomass and soils of tropical Asian forests. Geocarto Int 4:45-59

Brown IF, Martinelli LA, Thomas WW, Moreira MZ, Ferreira CA, Victoria RA (1995) Uncertainty in the biomass of Amazonian forests: an example from Rondonia, Brazil. For Ecol Manag 75:175-189
Chapin FS, Matson PA, Mooney HA (2002) Principles of terrestrial ecosystem ecology. Springer, New York

Chave J, Condit R, Muller-Landau HC, Thomas SC, Ashton PS, Bunyavejchewin S, Co LL, Dattaraja HS, Davies SJ, Esufali S, Ewango CEN, Feeley KJ, Foster RB, Gunatilleke N, Gunatilleke S, Hall P, Hart TB, Hernandez C, Hubbell SP, Itoh A, Kiratiprayoon S, Lafrankie JV, Loo de Lao S, Makana JR, Noor MNS, Kassim AR, Samper C, Sukumar R, Suresh HS, Tan S, Thompson J, Tongco MDC, Valencia R, Vallejo M, Villa G, Yamakura T, Zimmerman JK, Losos EC (2008) Assessing evidence for a pervasive alteration in tropical tree communities. PLoS Biol 6:e45

Dixon RK, Solomon AM, Brown S, Houghton RA, Trexler MC, Wisniewski J (1994) Carbon pools and flux of global forest ecosystems. Science 263:185-190

Djomo AN, Knohl A, Gravenhorst G (2011) Estimations of total ecosystem carbon pools distribution and carbon biomass current annual increment of a moist tropical forest. For Ecol Manag 261:1448-1459

Fahey TJ, Knapp AK (2007) Principles and standards for measuring primary production. Oxford University Press, New York

Gentry AH (1982) Patterns of neotropical plant species diversity. Evol Biol 15:1-84

Gibbon A, Silman MR, Malhi Y, Fisher JB, Meir P, Zimmermann M, Dargie GC, Farfan WR, Garcia KC (2010) Ecosystem carbon storage across the grassland-forest transition in the high Andes of Manu National Park, Peru. Ecosystems 13:1097-1111

Gibbs HK, Brown S, Niles JO, Foley JA (2007) Monitoring and estimating tropical forest carbon stocks: making REDD a reality. Environ Res Lett 2:1-13

Holdridge LR (1979) Ecologia Basada en Zonas de Vida. Editorial IICA, San Jose

Houghton RA, Hall F, Goetz SJ (2009) Importance of biomass in the global carbon cycle. J Geophys Res 114:G00E03

Kindermann GE, McCallum I, Fritz S, Obersteiner M (2008) A global forest growing stock, biomass and carbon map based on FAO statistics. Silva Fennica 42:387-396

Lasco RD, Guillermo IQ, Cruz RVO, Bantayan NC, Pulhin FB (2004) Carbon stocks assessment of a secondary forest in Mount Makiling Forest Reserve, Philippines. J Trop For Sci 16:35-45

Laurance WF, Laurance SG, Ferreira LV, Rankin-de-Merona JM, Gascon C, Lovejoy TE (1997) Biomass collapse in Amazonian forest fragments. Science 278:1117-1118

Laurance WF, Fearnside PM, Laurance SG, Delamonica P, Lovejoy TE, Rankin de Merona JM, Chambers JQ, Gascon C (1999) Relationship between soils and Amazon forest biomass: a landscape-scale study. For Ecol Manag 118:127-138

Le S (1996) Research on forest structure and proposal new selecting cutting system in Kon Ha Nung-Central Highlands. Ph.D. dissertation, Vietnam Forestry University, Hanoi

Lee S, Lee J, Kim S, Roh Y, Salim KA, Lee WK, Son W (2018) Forest structure and carbon dynamics of an intact lowland mixed dipterocarp forest in Brunei Darussalam. J For Res 29:199-203

Lewis SL, Phillips OL, Baker TR, Lloyd J, Malhi Y, Almeida S, Higuchi N, Laurance WF, Neill DA, Silva JNM, Terborgh J, Torres Lezama A, Vasquez Martınez R, Brown S, Chave J, Kuebler C, Nunez Vargas P, Vinceti B (2004) Concerted changes in tropical forest structure and dynamics: evidence from 50 South American long-term plots. Phil Trans R Soc B 359:421-436

Lewis SL, Lopez-Gonzalez G, Sonke B, Affum-Baffoe K, Baker TR, Ojo LO, Phillips OL, Reitsma JM, White L, Comiskey JA, Djuikouo MNK, Ewango CEN, Feldpausch TR, Hamilton AC, Gloor M, Hart T, Hladik A, Lloyd J, Lovett JC, Makana JR, Malhi Y, Mbago FM, Ndangalasi HJ, Peacock J, Peh KSH, Sheil D, Sunderland T, Swaine MD, Taplin J, Taylor D, Thomas SC, 
Votere R, Woll H (2009) Increasing carbon storage in intact African tropical forests. Nature 457:1003-1006

Lewis SL, Sonke B, Sunderland T, Begne SK, Lopez-Gonzalez G, van der Heijden GMF, Phillips OL, Affum-Baffoe K, Baker TR, Banin L, Bastin J, Beeckman H, Boeckx P, Bogaert J, Canniere CD, Chezeaux E, Clark CJ, Collins M, DjagbleteyG Noe M, Djuikouo K, Droissart V, Doucet J, Ewango CEN, Fauset S, Feldpausch TR, Foli EG, Gillet GF, Hamilton AC, Harris DJ, Hart TB, Haulleville TD, Hladik A, Hufkens K, Huygens D, Jeanmart P, Jeffery KJ, Kearsley E, Leal ME, Lloyd J, Lovett JC, Makana JR, Malhi Y, Marshall AR, Ojo L, Peh KSH, Pickavance G, Poulsen JR, Reitsma JM, Sheil D, Simo M, Steppe K, Taedoumg HE, Talbot J, Taplin JRD, Taylor D, Thomas SC, Toirambe B, Verbeeck H, Vleminckx J, White LJT, Willcock S, Woell H, Zemagho L (2013) Above-ground biomass and structure of 260 African tropical forests. Phil Trans R Soc B 368:20120295

Loarie SR, Asner GP, Field CB (2009) Boosted carbon emissions from Amazon deforestation. Geophys Res Lett 36:L14810

Lugo AE, Scatena FN (1996) Background and catastrophic tree mortality in tropical moist, wet, and rain forests. Biotropica 28:585-599

Malhi Y, Wood D, Baker TR, Wright J, Phillips OL, Cochrane T, Meir P, Chave J, Almeida S, Arroyo L, Higuchi N, Killeen TJ, Laurance SG, Laurance WF, Lewis SL, Monteagudo A, Neill DA, Vargas PN, Pitman NCA, Quesada CA, Salomao R, Silva JNM, Lezama AT, Terborgh J, Martinez RV, Vinceti B (2006) The regional variation of aboveground live biomass in oldgrowth Amazonian forests. Glob Change Biol 12:1107-1138

Malhi Y, Aragao LEOC, Metcalfe DB, Paiva R, Quesada CA, Almeida S, Anderson L, Brando P, Chambers JQ, Da Costa ACL, Hutyra LR, Oliveira P, Patino S, Pyle EH, Robertson AL, Teixeira LM (2009) Comprehensive assessment of carbon productivity, allocation and storage in three Amazonian forests. Glob Change Biol 15:1255-1274

MARD (2014) Annual statistical data for agriculture and rural development. Ministry of Agriculture \& Rural Development, Hanoi, Vietnam. http://fsiu.mard.gov.vn/data/khituong.htm. Accessed on 15 Nov 2017

Miles L, Kapos V (2008) Reducing greenhouse gas emissions from deforestation and forest degradation: global land-use implications. Science 320:1454-1455

Miller SD, Goulden ML, Hutyra LR, Keller M, Saleska SR, Wofsy SC, Figueira AMS, da Rocha HR, de Camargo PB (2011) Reduced impact logging minimally alters tropical rainforest carbon and energy exchange. Proc Natl Acad Sci 108:19431-19435

Muller-Landau HC, Condit RS, Harms KE, Marks CO, Thomas SC, Bunyavejchewin S, Chuyong G, Co L, Davies S, Foster R, Gunatilleke S, Gunatilleke N, Hart T, Hubbell SP, Itoh A, Kassim AR, Kenfack D, LaFrankie JV, Lagunzad D, Lee HS, Losos E, Makana JR, Ohkubo T, Samper C, Sukumar R, Sun IF, Supardi MNN, Tan S, Thomas D, Thompson J, Valencia RMIGV, Yamakura T, Zimmerman JK, Dattaraja HS, Esufali S, Hall P, He F, Hernandez C, Kiratiprayoon S, Suresh HS, Wills C, Ashton P (2006) Comparing tropical forest tree size distributions with the predictions of metabolic ecology and equilibrium models. Ecol Lett 9:589-602

Pan Y, Birdsey RA, Fang J, Houghton R, Kauppi PE, Kurz WA, Phillips OL, Shvidenko A, Lewis SL, Canadell JG, Ciais P, Jackson RB, Pacala SW, McGuire AD, Piao S, Rautiainen A, Sitch S, Hayes D (2011) A large and persistent carbon sink in the world's forests. Science 333:988-993

Pandian E, Parthasarathy N (2016) Decadal (2003-2013) changes in liana diversity, abundance and aboveground biomass in four inland tropical dry evergreen forest sites of peninsular India. J For Res 27:133-146

Paoli GD, Curran LM, Slik JWF (2008) Soil nutrients affect spatial patterns of aboveground biomass and emergent tree density in southwestern Borneo. Oecologia 155:287-299

Pearson TRH, Brown S, Casarim FM (2014) Carbon emissions from tropical forest degradation caused by logging. Environ Res Lett 9:034017

Phillips OL, Malhi Y, Higuchi N, Laurance WF, Nuenez PV, Vasquez RM, Laurance SG, Ferreira LV, Stern M, Brown S, Grace J (1998) Changes in the carbon balance of tropical forests: evidence from long-term plots. Science 282:439-442

Pires JM, Prance GT (1985) The vegetation types of the Brazilian Amazon. In: Lovejoy TE (ed) Prance GT. Pergamon Press, New York, pp 109-145

Quesada CA, Phillips OL, Schwarz M, Czimczik CI, Baker TR, Patino S, Fyllas NM, Hodnett MG, Herrera R, Almeida S, Alvarez Davila E, Arneth A, Arroyo L, Chao KJ, Dezzeo N, Erwin T, di Fiore A, Higuchi N, Honorio Coronado E, Jimenez EM, Killeen T, Lezama AT, Lloyd G, Lopez-Gonzalez G, Luizao FJ, Malhi Y, Monteagudo A, Neill DA, Nunez Vargas P, Paiva R, Peacock J, Penuela MC, Pena Cruz A, Pitman N, Priante Filho N, Prieto A, Ramirez H, Rudas A, Salomao R, Santos AJB, Schmerler J, Silva N, Silveira M, Vasquez R, Vieira I, Terborgh J, Lloyd J (2012) Basin-wide variations in Amazon forest structure and function are mediated by both soils and climate. Biogeosciences 9:2203-2246

Reilly MJ, Spies TA (2015) Regional variation in stand structure and development in forests of Oregon, Washington, and inland Northern California. Ecosphere 6:192

Saatchi SS, Houghton RA, dos Santos Alvala RC, Soares JV, Yu Y (2007) Distribution of aboveground live biomass in the Amazon basin. Glob Change Biol 13:816-837

Saldarriaga JG, West DC, Tharp ML, Uhl C (1988) Longterm chronosequence of forest succession in the upper Rio Negro of Colombia and Venezuela. J Ecol 76:938-958

Saner P, Loh YY, Ong RC, Hector A (2012) Carbon stocks and fluxes in tropical lowland dipterocarp rainforests in Sabah, Malaysian Borneo. PloS One 7:e29642

Schimel DS (1995) Terrestrial ecosystems and the carbon cycle. Glob Change Biol 1:77-91

Sierra CA, Del Valle IJ, Orrego SA, Moreno FH, Harmon MA, Zapata M, Colorado GJ, Herrera MA, Lara W, Restrepo DE, Berrouet LM, Loaiza LM, Benjumea JF (2007) Total carbon stocks in a tropical forest landscape of the Porce region, Columbia. For Ecol Manag 243:299-309

Slik JWF, Aiba SI, Brearley FQ, Cannon CH, Forshed O, Kitayama K, Nagamasu H, Nilus R, Payne J, Paoli G, Poulsen AD, Raes N, Sheil D, Sidiyasa K, Suzuki E, Van Valkenburg JLCH (2010) Environmental correlates of tree biomass, basal area, wood specific gravity and stem density gradients in Borneo's tropical forests. Glob Ecol Biogeo 19:50-60

Slik JW, Paoli G, McGuire K, Amaral I, BarrosoJ Bastian M, Blanc L, Bongers F, Boundja P, Clark C, Collins M, Dauby G, Ding Y, Doucet JL, Eler E, Ferreira L, Forshed O, Fredriksson G, Gillet JF, Harris D, Leal M, Laumonier Y, Malhi Y, Mansor A, Martin E, Miyamoto K, Araujo-Murakami A, Nagamasu H, Nilus R, Nurtjahya E, Oliveira A, Onrizal O, Parada-Gutierrez A, Permana A, Poorter L, Poulsen J, Ramirez-Angulo H, Reitsma J, Rovero F, Rozak A, Sheil D, Silva-Espejo J, Silveira M, Spironelo W, ter Steege H, Stevart T, Navarro-Aguilar GE, Sunderland T, Suzuki E, Tang J, Theilade I, van der Heijden G, van Valkenburg T, Tran VD, Vilanova E, Vos V, Wich S, Wöll H, Yoneda T, Zang R, Zhang MG, Zweifel N (2013) Large trees drive forest aboveground biomass variation in moist lowland forests across the tropics. Glob Ecol Biogeo 22:1261-1271 
Tashi S, Keitel C, Singh B, Adams M (2017) Allometric equations for biomass and carbon stocks of forests along an altitudinal gradient in the eastern Himalayas. Forestry 90:445-454

Tran VD, Akira O, Nguyen TT (2010) Recovery process of a mountain forest after shifting cultivation in Northwestern Vietnam. For Ecol Manag 259:1650-1659

Tran VD, Akira O, Nguyen TT, Nguyen BV, Bui TH, Cam QK, Le TT, Diep XT (2011) Population changes of early successional forest species after shifting cultivation in Northwestern Vietnam. New For 41:247-262

Tran VD, Ngo VC, Tamotsu S, Nguyen TB, Osamu K, Nguyen TT, Ralph M (2016) Post-logging regeneration and growth of commercially valuable tree species in evergreen broadleaf forest, Vietnam. J Trop For Sci 28:426-435

Tran VD, Phung DT, Mamoru Y, Osamu K, Nguyen TT, Dang VT, Hoang VT, Nguyen TTP, Ninh VK, Ngo VC (2017a) Aboveground biomass increment and stand dynamics in tropical evergreen broadleaved forest. J Sustain For 37:1-14

Tran VD, Tamotsu S, Vo DH, Nguyen TT, Nguyen TB, Nguyen HS, Dang VT, Bui TD, Hoang VT, Trieu TH, Tran VC, Osamu K, Le VT, Ngo VC (2017b) Aboveground phytomass and tree species diversity along altitudinal gradient in Central Highland, Vietnam. Trop Ecol 58:95-104

Tuomisto H, Ruokolainen K, Kalliola R, Linna A, Danjoy W, Rodriguez Z (1995) Dissecting Amazonian biodiversity. Science 269:63-66

Urquiza-Haas T, Dolman PM, Peres CA (2007) Regional scale variation in forest structure and biomass in the Yucatan Peninsula, Mexico: effects of forest disturbance. For Ecol Manag 247:80-90

Vo DH, Tran VD, Dang TT, Tamotsu S, Osamu K (2015) Carbon stocks in tropical evergreen broadleaf forests in Central Highland, Vietnam. Int Forest Rev 17:20-29

Westfall JA, McRoberts RE (2017) An assessment of uncertainty in volume estimates for stands reconstructed from tree stump information. Forestry 90:404-412

Zheng J, Wei X, Liu Y, Liu G, Wang W, Liu W (2016) Review of regional carbon counting methods for the Chinese major ecological engineering programs. J For Res 27(4):727-738

Publisher's Note Springer Nature remains neutral with regard to jurisdictional claims in published maps and institutional affiliations. 